The Egyptian Journal of Social Work (EJSW) www.ejsw.org

ISSN: 2356-9204

\title{
Effectiveness of NGO Programs in Achieving Social Protection for Poor Families
}

\section{Amal Mohammed Salameh Gobary}

High Institute of Social Work - Alexandria 



\begin{tabular}{||lr|}
\hline The Egyptian Journal of Social Work (EJSW) & www.ejsw.org \\
ISSN: $2356-9204$ & Vol 1, No.5, January 2018 \\
\hline
\end{tabular}

\title{
Effectiveness of NGO Programs in Achieving Social Protection for Poor Families
}

\author{
Amal Mohammed Salameh Gobary \\ High Institute of Social Work - Alexandria
}

\begin{abstract}
:
The study aimed to identify the realistic contribution that programs of non-governmental organizations (NGOs) make towards social protection for poor families. The study is based on the evaluation study method. The selection sample was based on a social survey of non-governmental organizations working to fight poverty. (5) NGOs were selected according to the following conditions: They provide services in poor neighborhoods, including basic services such as social, economic, educational and health services, as well as activities to improve the skills of poor families. The field of study reached (120) families who were undecided about the benefits of using the services of NGOs. The following conditions were observed: the families must receive skills development services and access to social services, and the average household income is less than LE1000 a month. The study is also based on the measure of the effectiveness of the programs prepared by the researcher. The study reached a number of results: The programs provided by NGOs need to be developed in light of the constantly changing needs of poor families; it is necessary to improve poor families' skills through easier access to self-development programs. These programs play a key part in achieving social protection in developing countries in particular, due to the lack of resources and low levels of income in these countries.

Key words: NGOs, social protection, poor families.

Introduction:

The implementation of economic reform policies adopted by some developing countries in an effort to implement structural stabilization and adjustment policies has had a negative impact increasing poverty rates in these countries, especially after the reduction of direct subsidies and the liberalization of prices. This has compounded the burden of low incomes and led to the inability of poor households to meet their basic needs (Abdul Ghaffar, S, 2007, p. 32 ). As a result of these global economic challenges, many developing countries have been subjected to intense pressures associated with the changing nature of social risks, poverty and unemployment (Nasr. S,
\end{abstract}




\section{The Egyptian Journal of Social Work (EJSW) www.eisw.org \\ ISSN: 2356-9204 Vol 1, No.5, January 2018}

2010, p.8). In light of this, poverty has become a clear challenge in developing countries, where the indicators show that hunger, disease and lack of education have increased among all sectors of society (Elkrdy, K, 2014, p. 8). In addition, more than $60 \%$ of the urban population in the least developed countries live in slums (Unger. A, 2013, pp.799-805).

All these factors have created a state of suffering which is experienced by about $66 \%$ of the households in the Egyptian countryside and $41.1 \%$ of households in urban areas, where high rates of poverty are related to unemployment, illiteracy, a high dependency ratio and lack of services (United Nation, Human Development Report 2008, p. 67). Poverty, through exclusion, usually arises from access to needs that are physiologically, physically, humanly and socially necessary, such as food and clean water, health, education, employment, public services, and social support systems. Poverty through exclusion or marginalization is thus determined by denial of access to these essential needs (Lilla, A, 2002, p. 311). In addition, poverty alleviation in the broad sense is the adequacy of public facilities available. Lack of access to these facilities, such as access to clean drinking water, leads to unsatisfied basic needs among citizens, which increases the poverty rates (United Nation-HABiTAT, 2015, p.1). The increase in life expectancy of the population depends on several factors, the most important of which is improving nutrition, improving the sources of clean water, sanitation and innovation in the technological and medical fields and public health services. All this depends on integrated, strong social protection programs. (Bhargava, A., Jamison, D. T., Lau, L. J. \& Murry, C. J 2001, pp.423-440).Over the past two decades, global and local attention has grown to the issues of poverty. Combating poverty and providing social protection to marginalized and disadvantaged groups in third world countries is recommended by international organizations such as the International Monetary Fund and the World Bank, following the restructuring policies on the economies of many of these countries (Nasr. S, 2010, p.8). The United Nations Research Institute for Social Development (UNRISD) notes that social protection aims to prevent, manage and overcome situations that negatively affect the welfare of citizens. Social protection consists of policies and programs aimed at reducing poverty and vulnerability by enhancing the efficiency of labor markets, and enhancing their ability to manage economic and social 


\section{The Egyptian Journal of Social Work (EJSW) www.eisw.org \\ ISSN: 2356-9204 Vol 1, No.5, January 2018}

risks such as unemployment, disease, disability and old age (Hagazy, A, 2014, p. 36).

Social protection can be defined, for the purposes of this study, as a set of measures, programs and activities provided by NGOs for social, health, educational and skills development for poor families, which mitigate the negative effects of high poverty rates.

The UN Executive Council has adopted an international initiative to achieve comprehensive social protection for $\mathrm{UN}$ Members. This initiative aims to strengthen the protection systems in member countries, providing basic social services and supporting the poor or vulnerable living in poverty. This initiative also aims to provide a decent life for members of the community, through comprehensive and integrated social protection (Alaolma, N, 2011, p. 4). Therefore, social protection has become one of the most important and necessary issues for all societies, through which people can live in safety, stability and tranquility. In its simplest sense, it is a group of social programs which work on the progression and advancement of man in all social, economic and psychological aspects (Quaidereider, I 2005, p. 12).

It is noted that this concept includes a series of protectionist measures that qualify a person to obtain his basic needs of clothing, food and medicine, and to guarantee the minimum standard of living. These economic measures are conducive to the creation of social and economic security measures providing psychological and physical well-being, as well as economic security. The social groups most in need of economic security are orphans, widows, the sick or disabled, the elderly and children (Al-Rubaie, F 2008, p. 1). Forms of social protection vary, but they include reducing the number of children in work, reducing discrimination between males and females, and achieving justice in women's affairs. (Al-Namla, A, 2014, p.2).

In light of this, social protection is crucial to accelerating poverty reduction as it can provide a measure of safety for individuals who do not benefit from economic growth. Social protection, if properly structured, can directly contribute to faster economic growth through the development of human resources and enhance the capacity of the poor, especially smallholders, to manage their own risks (FAO, 2012, p. 39).

Social protection networks are one of the cornerstones of social work in all its dimensions. Therefore, we find that through legislation, policies and charitable activities, countries seek to provide 


\section{The Egyptian Journal of Social Work (EJSW) www.ejsw.org \\ ISSN: 2356-9204 Vol 1, No.5, January 2018}

various services to needy and marginalized groups and to work on their rehabilitation and social integration in order to achieve family and social stability. However, there are many challenges and difficulties facing social protection systems in poor countries (Hamouda, H, 2005, p. 8). Social protection programs must therefore be seen as an essential tool for poverty eradication and inequality, especially when they target the most marginalized, poorest and needy groups (Waqas, M \& Awan, M.S. 2017, pp.369- 380).

According to World Bank data, social safety nets are inadequate or non-existent in many developing countries. At least 60 percent of people in developing countries do not have effective coverage of social safety nets and a human rights-based approach. In the recent past, the poor have become strongly supportive of the availability of social protection for them to maintain stability in society (FAO, 2012, p. 40). Especially since the analysis of social protection policies in developing countries indicate severe difficulties in addressing the effects of poverty, which means a reassessment of these policies is required to address persistent poverty and increasing inequality (Wagle, U.R, 2016, pp. 137-167).

Due to the lack of state-sponsored social protection networks, the role of non-governmental organizations (NGOs) as state partners in providing aid to the poor and needy, is extremely important. NGOs are an important and essential element in providing social protection networks, in terms of the means of social assistance they provide to poor families, and contributing to the achievement of sustainable economic and social development. The roles and effectiveness of these organizations vary from country to country due to many influential societal variables (Nasr. S, 2010, p.19).

The support provided by NGOs is highly effective in terms of their rapid adaptation to the needs of the poor, and their ability to mobilize people, and the fact that they are more connected to the community, so are familiar with their needs and requirements. However, NGOs must deal with government bureaucracy which often limits their effectiveness in providing the necessary services and their positive impact on achieving social cohesion (Hans, H, 2002, p.3), Modern NGOs are also focusing on community development in a holistic manner by providing training and skills to poor families, securing jobs and supporting small income-generating enterprises (Hamouda, H, 2005, p. 22). 


\begin{tabular}{||lr||}
\hline The Egyptian Journal of Social Work (EJSW) & www.ejsw.org \\
ISSN: $2356-9204$ & Vol 1, No.5, January 2018 \\
\hline
\end{tabular}

Despite the importance of NGOs and their role in achieving social security, the majority of these organizations suffer from many administrative, technical or financial difficulties that hinder them in achieving their objectives. There are organizations that continue to provide assistance but disregard the issues of their beneficiaries, and their role in skills development and awareness-raising is very limited (Abd- El Samad, M, 2005, p.68).

In light of the above, this study attempts to evaluate the effectiveness of the social protection programs, represented in the social, educational, health and economic programs of NGOs, in developing the skills of the poor families.

\section{Methodology:}

The main question: What is the effectiveness of NGO programs in achieving social protection for poor families?

\section{Sub-questions:}

A. What is the reality of the social services programs of NGOs in achieving social protection for poor families?

B. What is the reality of educational services of NGOs in achieving social protection for poor families?

C. What is the reality of the health services of NGOs in achieving social protection for poor families?

D. What is the reality of the economic services of NGOs in achieving social protection for poor families?

E. What is the reality of skills development programs of NGOs in achieving social protection for poor families?

F. What are the difficulties faced by NGOs in achieving social protection for poor families?

\section{Participant:}

- Type of study: This study used the evaluation study method to identify the effectiveness of NGO programs in achieving social protection for poor families, and form part of the scientific knowledge needed in the development of NGO services and programs.

- Methodology used: The study was based on the sample survey of NGOs working to fight poverty, totaling (5) organizations in Alexandria Governorate, as well as the comprehensive social survey of all the families served by those organizations, which amounted to (120) families.

- Sample of the study: The researcher developed a set of conditions for the selection of families. They were: families 


\begin{tabular}{||lr||}
\hline The Egyptian Journal of Social Work (EJSW) & www.ejsw.org \\
ISSN: $2356-9204$ & Vol 1, No.5, January 2018 \\
\hline
\end{tabular}

must use the services of the organization, including the poor families' skills development program, and the average income of the family must be less than LE1000 a month. (120) families met these conditions.

- The geographical area of the study: The field of study was identified in (5) NGOs working in the field of caring for poor families: Al-Dhahira Association, Al-Ameen Charitable Association for Community Development, Noor Al Islam Association, The Giag Development Foundation and the Islamic Ahal el Kher Society. These organizations are located in the poorest neighborhoods of Alexandria Governorate and are characterized by the following: They are NGOs that include various activities and programs for the poor, whether social, economic, and educational or health. They also have programs in developing the skills of poor families.

\section{Measures:}

The study was based on a measure prepared by the researcher entitled "Effectiveness of NGO Programs in Achieving Social Protection for Poor Families".

\section{Stages of setting the Scale:}

a) During this stage, a number of statements related to the subject of the study and its indicators were collected. The researcher relied on a number of sources: Reading the theoretical background and examining previous studies that dealt with similar variables on the subject of the study. The researcher also relied on interviews with some of the employees in the NGOs. The researcher concluded with six basic indicators for measuring each aspect of social protection for poor families.

b) The arbitration stage of the scale: The researcher presented the scale in its initial form to ten arbitrators with varying areas of expertise as follows: professors in social services, and experts in civil work and NGOs. (Language assessment for each term the extent to which the term is related to the sub-variable - the extent to which the term is related to the subject matter of the study - in addition to any other terms deemed important by the arbitrators). Accordingly, the researcher limited all notes of deletion and addition, and (11) words were not agreed upon by $(80 \%)$ of the arbitrators in the end, the measure after arbitration became a component (56) words. 


\section{The Egyptian Journal of Social Work (EJSW) www.eisw.org \\ ISSN: 2356-9204 Vol 1, No.5, January 2018}

c) Correction of the scale: A triple gradient has been established so that the response to each statement (yes - to some extent no) is balanced with weights (3.2.1), respectively. The overall score of the scale measured (168) degrees. The average score for the measure as a whole was (112), the smallest for the scale was (56).

d) Reliability and stability of the scale: The researcher calculated the reliability through the application of the scale to a sample of (10) cases, with a time difference of (15) days, and calculated the coefficient of stability using Alpha Kronbach's method for the final grades of the indicators of the scale. It showed the following:

Table (1) shows the coefficient of stability of the scale indicators

\begin{tabular}{||l||c||}
\hline \multicolumn{1}{|c|}{ Scale indicators } & $\begin{array}{c}\text { Alpha } \\
\text { Kronbach }\end{array}$ \\
\hline \hline Social services provided by NGOs & 0.91 \\
\hline \hline Educational services provided by NGOs & 0.89 \\
\hline \hline Medical services provided by NGOs & 0.90 \\
\hline \hline Economic services provided by NGOs & 0.88 \\
\hline \hline $\begin{array}{l}\text { Development of skills for poor households provided by } \\
\text { NGOs }\end{array}$ & 0.91 \\
\hline \hline Difficulties facing NGOs in achieving social protection & 0.90 \\
\hline \hline \multicolumn{2}{|c|}{ Total score of the scale } \\
\hline
\end{tabular}

The researcher obtained statistically significant stability coefficients at the mean level (0.01) for all axes of the scale. Giving a strong indicator of the reliability of the scale.

a) The scale is valid:

The researcher used the following methods to calculate the validity of the scale:

- Face validity: The researcher presented the standard to a group specialized in social services and community organizations as well as social work. The researcher requested feedback on the appropriate indicators and phrases to use for the objectives of the study, and validation of the wording used to describe the performance to be measured, as well as suggestions for any other amendments. The terms that the arbitrators decided to exclude were duly excluded, and the phrases that $(80 \%)$ of them agreed were valid were retained. 


\section{The Egyptian Journal of Social Work (EJSW) www.ejsw.org \\ ISSN: 2356-9204 Vol 1, No.5, January 2018}

- Validity of internal consistency: The accuracy of the correlation coefficients between the score of each indicator and the other indicators, as well as each indicator of the total grade of the scale was measured. The following table shows the results.

Table (2) shows the correlation between dimensions of measurement

\begin{tabular}{|c|c|c|c|c|c|c|}
\hline Dimensions & $\begin{array}{c}\text { social } \\
\text { services }\end{array}$ & $\begin{array}{c}\text { Education } \\
\text { al services }\end{array}$ & $\begin{array}{c}\text { Health } \\
\text { Services }\end{array}$ & $\begin{array}{c}\text { Economic } \\
\text { services }\end{array}$ & $\begin{array}{c}\text { Skills } \\
\text { Development }\end{array}$ & Obstacles \\
\hline $\begin{array}{c}\text { Social } \\
\text { services }\end{array}$ & & & & & & \\
\hline $\begin{array}{c}\text { Educational } \\
\text { services }\end{array}$ & 0.871 & & & & & \\
\hline $\begin{array}{c}\text { Health } \\
\text { Services }\end{array}$ & 0.901 & 0.902 & & & & \\
\hline $\begin{array}{c}\text { Economic } \\
\text { services }\end{array}$ & 0.881 & 0.881 & 0.941 & & & \\
\hline $\begin{array}{c}\text { Skills } \\
\text { Development }\end{array}$ & 0.776 & 0.886 & 0.981 & 0.789 & & \\
\hline Obstacles & 0.787 & 0.774 & 0.886 & 0.845 & 0.845 & 0.810 \\
\hline Total & 0.891 & 0.881 & 0.901 & 0.861 & 0.855 & \\
\hline
\end{tabular}

It is clear from the previous table that all the indicators are related to each other and the total score of the scale is statistically significant at a level of $(0.05-0.01)$. This confirms the validity of the internal consistency of the scale.

Statistical Analysis:

- The researcher used both weighted weights, and relative strength to estimate respondents' answers. These methods are based on simple calculations such as arithmetic mean and standard deviation.

- The Alpha Kronbach method was used to detect the correlations between the dimensions of the scale and to find the value of the coefficient of stability of the scale by reapplication.

- Calculate the proportion of the agreement with respect to the veracity of the arbitrators of the standard vocabulary.

- The Pearson correlation coefficient was used to determine the relationship between social protection programs. 


\begin{tabular}{|lr|}
\hline The Egyptian Journal of Social Work (EJSW) & www.ejsw.org \\
ISSN: 2356-9204 & Vol 1, No.5, January 2018 \\
\hline
\end{tabular}

Results:

A. Results of the first question of the study: What is the reality of social services programs provided by NGOs in achieving social protection for poor families?

Table (3) shows the reality of social services provided by NGOs to poor families

\begin{tabular}{|c|c|c|c|c|c|c|c|c|c|}
\hline \multirow{3}{*}{ Statements } & \multicolumn{6}{|c|}{ Responses of respondents } & \multicolumn{3}{|c|}{ Statistical Analysis } \\
\hline & \multicolumn{2}{|c|}{ Agree } & \multicolumn{2}{|c|}{ Sometimes } & \multicolumn{2}{|c|}{ Disagree } & \multirow{2}{*}{$\mathbf{E x}$} & \multirow{2}{*}{$\overline{\mathbf{x}} \mathbf{w}$} & \multirow{2}{*}{ Arrangement } \\
\hline & No & $\%$ & No & $\%$ & No & $\%$ & & & \\
\hline $\begin{array}{l}\text { Provide activities to support the } \\
\text { positive values of poor families }\end{array}$ & 23 & 19.2 & 96 & 80.0 & 1 & 0.8 & 262 & 2.18 & 1 \\
\hline $\begin{array}{|ll|}\begin{array}{l}\text { Provide recreational services for } \\
\text { poor families }\end{array} & \\
\end{array}$ & 25 & 20.8 & 25 & 20.8 & 70 & 58.3 & 195 & 1.62 & 8 \\
\hline $\begin{array}{l}\text { Organize programs to reduce } \\
\text { negative consumer behavior of poor } \\
\text { families }\end{array}$ & 12 & 10.0 & 41 & 34.2 & 67 & 55.8 & 185 & 1.54 & 9 \\
\hline $\begin{array}{l}\text { Provide community partnerships } \\
\text { between poor families and the local } \\
\text { community }\end{array}$ & 13 & 10.8 & 63 & 52.5 & 44 & 36.7 & 209 & 1.74 & 7 \\
\hline $\begin{array}{l}\text { Organize seminars to reduce the } \\
\text { negative effects of poverty }\end{array}$ & 18 & 15.0 & 89 & 74.2 & 13 & 10.8 & 245 & 2.04 & 3 \\
\hline $\begin{array}{l}\text { Provide reproductive health } \\
\text { awareness programs for members of } \\
\text { poor families }\end{array}$ & 14 & 11.7 & 105 & 87.5 & 1 & 0.8 & 253 & 2.10 & 2 \\
\hline $\begin{array}{l}\text { Organize meetings for families to } \\
\text { overcome their social problems }\end{array}$ & 16 & 13.3 & 73 & 60.8 & 31 & 25.8 & 225 & 1.87 & 5 \\
\hline $\begin{array}{l}\begin{array}{l}\text { Conduct exploratory research to } \\
\text { identify the most geographically poor } \\
\text { cases }\end{array} \\
\end{array}$ & 21 & 17.5 & 71 & 59.2 & 28 & 23.3 & 233 & 1.94 & 4 \\
\hline Help solve family problems & 44 & 36.7 & 6 & 5.0 & 70 & 58.3 & 214 & 1.78 & 6 \\
\hline$\varepsilon$ & \multicolumn{2}{|c|}{186} & \multicolumn{2}{|c|}{569} & \multicolumn{2}{|c|}{325} & 2012 & \multicolumn{2}{|c|}{$\left(\mathrm{SMA}^{*}\right)=16.84$} \\
\hline$\overline{\mathbf{x}}$ & \multicolumn{2}{|c|}{20.7} & \multicolumn{2}{|c|}{63.2} & \multicolumn{2}{|c|}{36.1} & 120 & \multirow{2}{*}{\multicolumn{2}{|c|}{$(\mathrm{RS})=62.3 \%$}} \\
\hline$\%$ & & $2 \%$ & & $7 \%$ & & $1 \%$ & $100 \%$ & & \\
\hline
\end{tabular}

The results of the previous table on social services provided by NGOs showed that the majority of the sample responded "to some extent" (52.7\%), followed by "no" (30.1\%), then "yes" (17.2\%). The relative strength of social services $(62.3 \%)$ is also indicative of the fact that the services provided by NGOs rate in the middle stage.

When placing the social services provided in descending order according to the arithmetic mean, the following is shown: First was "Provide activities to support the positive values of poor families" which recorded an average of (2.18). Second was "Provide reproductive health awareness programs for members of poor families", with an average of (2.10). Third was "Organize seminars to reduce the negative effects of poverty" with an average of (2.04). Fourth was "conduct exploratory research to identify the most geographically poor cases" with an average of (1.94); and fifth,

- $($ SMA $)=$ Arithmetic mean $/($ R.S $)=$ Relative Strength 


\section{The Egyptian Journal of Social Work (EJSW) www.ejsw.org \\ ISSN: 2356-9204 Vol 1, No.5, January 2018}

"Organize meetings for families to overcome their social problems", calculated on average (1.87). Ranked sixth was "help solve family problems" with an average of (1.78), and ranked seventh was "Provide community partnerships between poor families and the local community" with an average of (1.74). Eighth was "Provide recreational services for poor families" with an average of (1.62) finally, ninth was "Organize programs to reduce the negative consumer behavior of poor households" with an average of (1.54).

B. Results of the second question: What is the reality of educational services provided by NGOs in achieving social protection for poor families?

Table (4) shows the reality of educational services provided by

NGOs to poor families

\begin{tabular}{|c|c|c|c|c|c|c|c|c|c|}
\hline \multirow{3}{*}{ Statements } & \multicolumn{6}{|c|}{ Responses of respondents } & \multicolumn{3}{|c|}{ Statistical Analysis } \\
\hline & \multicolumn{2}{|c|}{ Agree } & \multicolumn{4}{|c|}{ Sometimes Disagree } & \multirow{2}{*}{$\varepsilon x$} & \multirow{2}{*}{$\overline{\mathbf{x}} \mathbf{w}$} & \multirow{2}{*}{ Arrangement } \\
\hline & No & $\%$ & No & $\%$ & No & $\%$ & & & \\
\hline $\begin{array}{l}\text { Provide literacy classes to } \\
\text { educate poor family members }\end{array}$ & 11 & 9.2 & 67 & 55.8 & 42 & 35.0 & 209 & 1.74 & 3 \\
\hline \begin{tabular}{|c|} 
Provide financial assistance to \\
pay tuition fees to their children
\end{tabular} & 9 & 7.5 & 106 & 88.3 & 5 & 4.2 & 244 & 2.03 & 2 \\
\hline $\begin{array}{c}\text { Enroll children who drop out of } \\
\text { education with new schools }\end{array}$ & 17 & 14.2 & 35 & 29.2 & 68 & 56.7 & 189 & 1.57 & 4 \\
\hline \begin{tabular}{|c|} 
Provide schools with tools and \\
school uniforms for the children \\
of poor families
\end{tabular} & 22 & 18.3 & 94 & 78.3 & 4 & 3.3 & 258 & 2.15 & 1 \\
\hline $\begin{array}{c}\text { Form study support groups for } \\
\text { students from poor families }\end{array}$ & 21 & 17.5 & 7 & 5.8 & 92 & $76.7 \mid$ & 169 & 1.41 & 7 \\
\hline \begin{tabular}{|c|} 
Hold educational seminars for \\
poor families to reduce dropouts
\end{tabular} & 19 & 15.8 & 33 & 27.5 & 68 & 56.7 & 191 & 1.59 & 5 \\
\hline $\begin{array}{l}\text { Provide a library with a variety } \\
\text { of books to encourage reading }\end{array}$ & 22 & 18.3 & 28 & 23.3 & 70 & 58.3 & 192 & 1.6 & 6 \\
\hline$\varepsilon$ & \multicolumn{2}{|c|}{121} & \multicolumn{2}{|c|}{370} & \multicolumn{2}{|c|}{349} & 1452 & \multicolumn{2}{|c|}{$($ SMA $)=12.1$} \\
\hline$\overline{\mathbf{x}}$ & \multicolumn{2}{|c|}{17.28} & \multicolumn{2}{|c|}{52.85} & \multicolumn{2}{|c|}{49.85} & 120 & \multirow{2}{*}{\multicolumn{2}{|c|}{$(\mathrm{RS})=\mathbf{5 7 . 6 \%}$}} \\
\hline$\%$ & & $4 \%$ & & $1 \%$ & & $5 \%$ & $100 \%$ & & \\
\hline
\end{tabular}

The results of the previous table on educational services provided by NGOs showed that the majority of the sample responded "to some extent" (44.1\%) to the educational services provided, followed by "No" (41.5\%), and then "Yes" (14.4\%). The relative strength of educational services was $(57.6 \%)$, indicating that educational services provided to poor families are average.

When placing the educational services provided in descending order according to the mean, the following is shown: First, "Provide schools with tools and school uniforms for the children of poor families", calculated at an average of (2.15). Second was "provide financial assistance to pay the expenses of their students" with an 


\section{The Egyptian Journal of Social Work (EJSW) www.ejsw.org \\ ISSN: 2356-9204 Vol 1, No.5, January 2018}

average of (2.03). Third was "Provide literacy classes to educate poor family members" with an average of (1.74). Fourth was "enroll children who drop out of education with new schools", with an average of (1.57), and the fifth was "hold educational seminars for poor families to reduce dropouts" with an average of (1.59). The sixth was "provide a library with a variety of books to encourage reading" with an average of (1.6), and the seventh was "form study support groups for students from poor families" with an average of (1.41).

C. Results of the third question: What is the reality of health services provided by NGOs in achieving social protection for poor families?

Table (5) shows the reality of health services provided by NGOs to poor families

\begin{tabular}{|c|c|c|c|c|c|c|c|c|c|}
\hline \multirow{3}{*}{ Statements } & \multicolumn{6}{|c|}{ Responses of respondents } & \multicolumn{3}{|c|}{ Statistical Analysis } \\
\hline & \multicolumn{2}{|c|}{ Agree } & \multicolumn{2}{|c|}{ Sometimes } & \multicolumn{2}{|c|}{ Disagree } & \multirow{2}{*}{$\mathbf{E x}$} & \multirow{2}{*}{$\overline{\mathbf{x}} \mathbf{w}$} & \multirow{2}{*}{$\begin{array}{c}\text { Arran } \\
\text { gemen } \\
\mathbf{t}\end{array}$} \\
\hline & No & $\%$ & No & $\%$ & No & $\%$ & & & \\
\hline $\begin{array}{l}\text { Provide medical services with nominal } \\
\text { fees }\end{array}$ & 9 & 7.5 & 111 & 92.5 & 0 & 0.0 & 249 & 2.07 & 3 \\
\hline $\begin{array}{l}\text { Provide free medical examinations for } \\
\text { patients from poor families }\end{array}$ & 15 & 12.5 & 55 & 45.8 & 50 & 41.7 & 205 & 1.71 & 8 \\
\hline $\begin{array}{l}\text { Provide free medical treatment for } \\
\text { poor families }\end{array}$ & 20 & 16.7 & 50 & 41.7 & 50 & 41.7 & 210 & 1.75 & 7 \\
\hline $\begin{array}{l}\text { Provide free medical analysis services } \\
\text { to poor families }\end{array}$ & 23 & 19.2 & 48 & 40.0 & 49 & 40.8 & 214 & 1.78 & 6 \\
\hline $\begin{array}{|llll|}\begin{array}{l}\text { Perform free surgeries for poor } \\
\text { families }\end{array} & & \\
\end{array}$ & 20 & 16.7 & 100 & 83.3 & 0 & 0.0 & 260 & 2.16 & 1 \\
\hline $\begin{array}{l}\text { Organize first aid training courses for } \\
\text { poor families }\end{array}$ & 20 & 16.7 & 45 & 37.5 & 55 & 45.8 & 205 & 1.71 & 8 \\
\hline $\begin{array}{|lcccc|}\text { Provide } & \text { medical care } & \text { for } & \text { cases } \\
\text { requiring } & \text { periodic } & \text { care } & \text { for } & \text { poor } \\
\text { families } & & & & \\
\end{array}$ & 15 & 12.5 & 79 & 65.8 & 26 & 21.7 & 229 & 1.91 & 5 \\
\hline $\begin{array}{l}\text { Provide compensatory devices for poor } \\
\text { families }\end{array}$ & 16 & 13.3 & 78 & 65.0 & 26 & 21.7 & 230 & 1.92 & 4 \\
\hline $\begin{array}{l}\text { Provide emergency first aid for poor } \\
\text { families }\end{array}$ & 18 & 15.0 & 22 & 18.3 & 80 & 66.7 & 178 & 1.48 & 10 \\
\hline $\begin{array}{l}\text { Provide medical services for pregnant } \\
\text { mothers from poor families }\end{array}$ & 19 & 15.8 & 101 & 84.2 & 0 & 0.0 & 259 & 2.15 & 2 \\
\hline $\begin{array}{l}\text { Organize medical convoys to provide } \\
\text { health and medical education to poor } \\
\text { families }\end{array}$ & 21 & 17.5 & 30 & 25.0 & 69 & 57.5 & 192 & 1.6 & 9 \\
\hline$\varepsilon$ & \multicolumn{2}{|c|}{196} & \multicolumn{2}{|c|}{719} & \multicolumn{2}{|c|}{405} & 2431 & \multicolumn{2}{|c|}{$\begin{array}{c}(\text { SMA })= \\
20.25\end{array}$} \\
\hline$\overline{\mathbf{x}}$ & \multicolumn{2}{|c|}{17.8} & \multicolumn{2}{|c|}{65.4} & \multicolumn{2}{|c|}{36.8} & 120 & \multirow{2}{*}{\multicolumn{2}{|c|}{$(\mathrm{RS})=61.3 \%$}} \\
\hline$\%$ & \multicolumn{2}{|c|}{$14.8 \%$} & \multicolumn{2}{|c|}{$54.5 \%$} & \multicolumn{2}{|c|}{$30.7 \%$} & $100 \%$ & & \\
\hline
\end{tabular}

The results of the previous table on medical services provided by NGOs showed that the majority of respondents agreed with statements about these services "to some extent" (54.5\%), followed by "no" (30.7\%), then "yes" (14.8\%). The relative strength of medical services was $(61.3 \%)$, indicating a moderate degree of medical services provided by associations to poor families. 


\section{The Egyptian Journal of Social Work (EJSW) www.ejsw.org \\ ISSN: 2356-9204 \\ Vol 1, No.5, January 2018}

When placing the medical services provided in descending order according to the mean, the following is shown: First, the phrase "perform free surgeries for poor families" calculated an average of (2.16). Second was "provide medical services for pregnant mothers from poor families" with an average of (2.15). Third was "Provide medical services at nominal fees" with an average of (2.07), the fourth "provide compensatory devices for poor families" with an average of (1.92), and the fifth "provide medical care for cases requiring periodic care for poor families" with an average of (1.91). The sixth was " provide free medical treatment for poor families" with an average of (1.78), and the seventh was "provide free medical treatment for poor families" with an average of (1.75). The eighth was "provide free medical examinations for patients from poor families" and "Organize first aid training courses for poor families" both with an average of (1.71). The ninth was "Organize medical convoys to provide health and medical education to poor families" with an average of (1.6). Lastly, the tenth was "Provide emergency first aid for poor families" with an average of (1.48).

Results of the fourth question: What is the reality of economic services provided by NGOs in achieving social protection for poor families?

Table (6) shows the reality of economic services provided by NGOs to poor families

\begin{tabular}{|c|c|c|c|c|c|c|c|c|c|}
\hline \multirow{3}{*}{ Statements } & \multicolumn{6}{|c|}{ Responses of respondents } & \multicolumn{3}{|c|}{ Statistical Analysis } \\
\hline & \multicolumn{2}{|c|}{ Agree } & \multicolumn{2}{|c|}{ Sometimes } & \multicolumn{2}{|c|}{ Disagree } & \multirow{2}{*}{$\varepsilon x$} & \multirow{2}{*}{$\overline{\mathbf{x}} \mathbf{w}$} & \multirow{2}{*}{$\underset{n t}{\text { Arrangeme }}$} \\
\hline & No & $\%$ & No & $\%$ & No & $\%$ & & & \\
\hline $\begin{array}{l}\text { Provide financial assistance to poor } \\
\text { families }\end{array}$ & 18 & 15.0 & 102 & 85.0 & 0 & 0.0 & 258 & 2.15 & 2 \\
\hline $\begin{array}{l}\begin{array}{l}\text { Provide job opportunities for some } \\
\text { members of poor families }\end{array} \\
\end{array}$ & 20 & 16.7 & 30 & 25.0 & 70 & 58.3 & 190 & 1.58 & 7 \\
\hline $\begin{array}{l}\text { Facilitate access to small loans from } \\
\text { banks to poor households }\end{array}$ & 15 & 12.5 & 59 & 49.2 & 46 & 38.3 & 209 & 1.74 & 5 \\
\hline $\begin{array}{l}\text { Assist in the establishment and } \\
\text { implementation of some production } \\
\text { projects }\end{array}$ & 17 & 14.2 & 57 & 47.5 & 46 & 38.3 & 211 & 1.75 & 4 \\
\hline $\begin{array}{l}\text { Assist in marketing the products of } \\
\text { projects implemented by households }\end{array}$ & 19 & 15.8 & 56 & 46.7 & 45 & 37.5 & 214 & 1.78 & 3 \\
\hline $\begin{array}{l}\text { Provide financial support for the } \\
\text { establishment of small production } \\
\text { projects }\end{array}$ & 22 & 18.3 & 30 & 25.0 & 68 & 56.7 & 194 & 1.61 & 6 \\
\hline $\begin{array}{l}\text { Provide consultation on the nature of } \\
\text { the projects that can be established }\end{array}$ & 17 & 14.2 & 8 & 6.7 & 95 & 79.2 & 162 & 1.35 & 8 \\
\hline \begin{tabular}{|lll}
$\begin{array}{l}\text { Train poor family members to } \\
\text { obtain jobs }\end{array}$ & \\
\end{tabular} & 18 & 15.0 & 55 & 45.8 & 47 & 39.2 & 211 & 1.75 & 4 \\
\hline $\begin{array}{l}\text { Provide financial and in-kind } \\
\text { assistance in case of disasters and } \\
\text { crises for poor families }\end{array}$ & 21 & 17.5 & 98 & $81.7 \mid$ & 1 & 0.8 & 260 & 2.16 & 1 \\
\hline$\varepsilon$ & \multicolumn{2}{|c|}{167} & \multicolumn{2}{|c|}{495} & \multicolumn{2}{|c|}{$\frac{1}{418}$} & 1909 & \multicolumn{2}{|c|}{$($ SMA $)=15.90$} \\
\hline$\overline{\mathbf{x}}$ & \multicolumn{2}{|c|}{18.9} & \multicolumn{2}{|c|}{55} & \multicolumn{2}{|c|}{46.4} & 120 & \multirow{2}{*}{\multicolumn{2}{|c|}{$(\mathrm{RS})=\mathbf{5 8 . 9} \%$}} \\
\hline$\%$ & & $5 \%$ & & $8 \%$ & & $7 \%$ & $100 \%$ & & \\
\hline
\end{tabular}




\section{The Egyptian Journal of Social Work (EJSW) www.ejsw.org \\ ISSN: 2356-9204

The results of the previous table on economic services provided by NGOs showed that the majority of the sample indicated that these services were happening "to some extent" (45.8\%), followed by "No" (38.7\%), and then "Yes" (15.5\%). The relative strength of economic services was also (58.9\%), indicating a moderate degree of economic services provided by associations to poor families.

When placing the economic services provided in descending order according to the mean, the following is shown: The first rank was "Provide financial and in-kind assistance in case of disasters and crises for poor families" with an average of (2.16), and the second was "provide financial assistance to poor families" with an average of (2.15). Third came "Assist in marketing the products of projects implemented by households" with an average of (1.78). The fourth was "Assist in the establishment and implementation of some production projects" and "Train poor family members to obtain employment", both with an average of (1.75). Fifth was " Facilitate access to small loans from banks to poor households with an average of (1.74). The sixth rank "provide financial support for the establishment of small production projects" recorded an average of (1.61), the seventh rank was "Provide job opportunities for some members of poor families" with an average of (1.58), and lastly, the eighth was "Provide consultation on the nature of the projects that can be established" with an average of (1.35). 


\begin{tabular}{|lr|}
\hline The Egyptian Journal of Social Work (EJSW) & www.ejsw.org \\
ISSN: 2356-9204 & Vol 1, No.5, January 2018 \\
\hline
\end{tabular}

D. Results of the fifth question: What is the reality of development services provided by NGOs in achieving social protection for poor families?

Table (7) shows the reality of poor family skills development activities provided by NGOs to poor families

\begin{tabular}{|c|c|c|c|c|c|c|c|c|c|}
\hline \multirow{3}{*}{ Statements } & \multicolumn{6}{|c|}{ Responses of respondents } & \multicolumn{3}{|c|}{ Statistical Analysis } \\
\hline & \multicolumn{2}{|c|}{ Agree } & \multicolumn{4}{|c|}{ Sometimes Disagree } & \multirow{2}{*}{$8 x$} & \multirow{2}{*}{\begin{tabular}{|l|}
$\mathbf{x}$ \\
$W$
\end{tabular}} & \multirow{2}{*}{ Arrangement } \\
\hline & No & $\%$ & No & $\%$ & No & $\%$ & & & \\
\hline $\begin{array}{l}\text { Enlighten poor households of } \\
\text { services in the local community }\end{array}$ & 16 & 13.3 & 100 & 83.3 & 4 & 3.3 & 252 & 2.1 & 2 \\
\hline $\begin{array}{l}\text { Establish training courses to } \\
\text { teach appropriate professional } \\
\text { craftsmanship }\end{array}$ & 21 & 17.5 & 54 & 45.0 & 45 & 37.5 & 216 & 1.8 & 5 \\
\hline $\begin{array}{l}\text { Provide economic marketing } \\
\text { skills for the products of their } \\
\text { projects }\end{array}$ & 18 & 15.0 & 32 & 26.7 & 70 & 58.3 & 188 & 1.56 & 9 \\
\hline $\begin{array}{|lccc|}\text { Develop skills to help } & \text { poor } \\
\text { families } & \text { solve } & \text { their } & \text { social } \\
\text { problems } & & & \\
\end{array}$ & 14 & 11.7 & 38 & 31.7 & 68 & 56.7 & 186 & 1.55 & 10 \\
\hline $\begin{array}{l}\text { Develop awareness of legal rights } \\
\text { and rules of work and methods } \\
\text { of obtaining them }\end{array}$ & 20 & 16.7 & 97 & 80.8 & 3 & 2.5 & 257 & 2.14 & 1 \\
\hline $\begin{array}{l}\text { Develop life skills to overcome } \\
\text { the risks of poverty }\end{array}$ & 15 & 12.5 & 35 & 29.2 & 70 & 58.3 & 185 & 1.54 & 11 \\
\hline $\begin{array}{l}\text { Develop the communication } \\
\text { skills of different institutions to } \\
\text { obtain services for the poor }\end{array}$ & 17 & 14.2 & 37 & 30.8 & 66 & 55.0 & 191 & 1.59 & 8 \\
\hline $\begin{array}{l}\text { Provide poor family members } \\
\text { with the addresses and telephone } \\
\text { numbers of bodies that can } \\
\text { provide them with services }\end{array}$ & 16 & 13.3 & 78 & 65.0 & 26 & 21.7 & 230 & 1.91 & 4 \\
\hline $\begin{array}{l}\text { Develop the cultural, social and } \\
\text { health awareness of poor } \\
\text { families }\end{array}$ & 20 & 16.7 & 76 & 63.3 & 24 & 20.0 & 236 & 196 & 3 \\
\hline $\begin{array}{l}\text { Develop the basic skills required } \\
\text { by the labor market }\end{array}$ & 19 & 15.8 & 53 & 44.2 & 48 & 40.0 & 211 & 1.75 & 6 \\
\hline $\begin{array}{l}\text { Develop community } \\
\text { participation skills to contribute } \\
\text { to problem solving }\end{array}$ & 22 & 18.3 & 44 & 36.7 & 54 & 45.0 & 208 & 1.73 & 7 \\
\hline$\varepsilon$ & 15 & 98 & 6 & 44 & & 78 & 2360 & & MA) $=19.6$ \\
\hline$\overline{\mathbf{x}}$ & 1 & 8 & & .5 & & 3.5 & 120 & & \\
\hline$\%$ & 15 & $\%$ & & $8 \%$ & & $2 \%$ & $100 \%$ & & \\
\hline
\end{tabular}

The results of the previous table showing the effectiveness of skills development activities provided by NGOs to poor families recorded that the majority of the sample responded that these services are available "to some extent" $(48.8 \%)$, followed by those who responded that they are not available at $(36.2 \%)$, and the respondents who answered with yes (15\%). The relative strength (59.6\%) indicates that these activities are generally satisfactory. 


\begin{tabular}{|lr|}
\hline The Egyptian Journal of Social Work (EJSW) & www.ejsw.org \\
ISSN: 2356-9204 & Vol 1, No.5, January 2018 \\
\hline
\end{tabular}

When placing these activities in descending order according to the arithmetic average, the following was shown: the first ranked was "Develop awareness of legal rights and rules of work and methods of obtaining them", with an average of (2.14). Second ranked was "Enlighten the poor households of services in the local community", with an average of (2.1). Third was "Develop the cultural, social and health awareness of poor families", with an average of (1.96), and ranked fourth was "Provide poor families with the addresses and telephone numbers of bodies that can provide services", with an average of (1.91). The fifth ranked was "Establish training courses to teach appropriate professional craftsmanship", with an average of (1.8). Sixth was "Develop the basic skills required by the labor market", with an average of (1.75), and the seventh rank "Develop the skills of community participation to contribute to solving problems" recorded an average of (1.73). The eighth ranking "Develop the communication skills of different institutions to obtain services for the poor" recorded (1.59), and the ninth rank, "Provide economic marketing skills for their project products" recorded an average of (1.56). The tenth ranked was "Develop skills to help poor families solve their social problems", with an average of (1.55). Lastly, the eleventh ranked was "Develop life skills to overcome the risks of poverty", with an average of (1.54).

E. Results of the sixth question: What are the difficulties faced by NGOs in achieving social protection for poor families?

Table (8) shows the difficulties faced by NGOs in achieving social protection for poor families

\begin{tabular}{|c|c|c|c|c|c|c|c|c|c|}
\hline \multirow{3}{*}{ Statements } & \multicolumn{6}{|c|}{ Responses of respondents } & \multicolumn{3}{|c|}{ Statistical Analysis } \\
\hline & \multicolumn{2}{|c|}{ Agree } & \multicolumn{2}{|c|}{ Sometimes } & \multicolumn{2}{|c|}{ Disagree } & \multirow{2}{*}{$E x$} & \multirow{2}{*}{$\overline{\mathbf{x}} \mathbf{w}$} & \multirow{2}{*}{$\begin{array}{c}\text { Arrange } \\
\text { ment }\end{array}$} \\
\hline & No & $\%$ & No & $\%$ & No & $\%$ & & & \\
\hline $\begin{array}{l}\text { Insufficient financial } \\
\text { resources to meet the needs } \\
\text { of poor families }\end{array}$ & 105 & 87.5 & 12 & 10.0 & 3 & 2.5 & 342 & 2.85 & 1 \\
\hline $\begin{array}{l}\text { Inadequate services } \\
\text { provided for poor families' } \\
\text { needs and priorities }\end{array}$ & 104 & 86.7 & 14 & 11.7 & 2 & 1.7 & 342 & 2.85 & 1 \\
\hline $\begin{array}{l}\text { Lack of availability of } \\
\text { professional staff working } \\
\text { as service providers to poor } \\
\text { families }\end{array}$ & 99 & 82.5 & 19 & 15.8 & 2 & 1.7 & 337 & $\begin{array}{c}2.81 \\
2\end{array}$ & 5 \\
\hline $\begin{array}{l}\text { Difficulty of administrative } \\
\text { procedures when accessing } \\
\text { services for poor families }\end{array}$ & 102 & 85.0 & 16 & 13.3 & 2 & 1.7 & 340 & 2.83 & 2 \\
\hline $\begin{array}{l}\text { Weakness of the value of } \\
\text { financial assistance } \\
\text { provided to poor families }\end{array}$ & 102 & 85.0 & 16 & 13.3 & 2 & 1.7 & 340 & 2.83 & 2 \\
\hline
\end{tabular}




\section{\begin{tabular}{||lr||}
\hline $\begin{array}{l}\text { The Egyptian Journal of Social Work (EJSW) } \\
\text { ISSN: 2356-9204 }\end{array}$ & Www.eisw.org \\
\hline
\end{tabular}}

\begin{tabular}{|c|c|c|c|c|c|c|c|c|c|}
\hline $\begin{array}{ll}\text { Lack of continuity of } \\
\text { disbursement } \\
\text { miscellaneous aid provided } \\
\text { to poor families }\end{array}$ & 100 & 83.3 & 18 & 15.0 & 2 & 1.7 & 338 & $\begin{array}{c}2.81 \\
5\end{array}$ & 4 \\
\hline $\begin{array}{l}\text { Lack of a scientific } \\
\text { database to determine the } \\
\text { actual needs of poor } \\
\text { households }\end{array}$ & 100 & 83.3 & 19 & 15.8 & 1 & 0.8 & 339 & 2.82 & 3 \\
\hline $\begin{array}{l}\text { Non-cooperation of various } \\
\text { institutions in providing } \\
\text { programs and services to } \\
\text { poor families }\end{array}$ & 98 & 81.7 & 20 & 16.7 & 2 & 1.7 & 336 & 2.8 & 6 \\
\hline $\begin{array}{l}\text { Lack of suitable places to } \\
\text { provide services to poor } \\
\text { families }\end{array}$ & 97 & 80.8 & 21 & 17.5 & 2 & 1.7 & 335 & 2.79 & 7 \\
\hline$\varepsilon$ & \multicolumn{2}{|c|}{907} & \multicolumn{2}{|c|}{155} & \multicolumn{2}{|c|}{18} & 3049 & \multicolumn{2}{|c|}{$($ SMA $)=19.6$} \\
\hline$\overline{\mathbf{x}}$ & \multicolumn{2}{|c|}{100.8} & \multicolumn{2}{|c|}{17.2} & \multicolumn{2}{|c|}{2} & 120 & \multirow{2}{*}{\multicolumn{2}{|c|}{$(\mathrm{RS})=94.1 \%$}} \\
\hline$\%$ & & $\%$ & & $3 \%$ & & $7 \%$ & $100 \%$ & & \\
\hline
\end{tabular}

The results of the previous table on the difficulties faced by NGOs in achieving social protection for poor households, showed that the majority of respondents answered "yes" (84\%), followed by "to some extent" (14.3\%), and then "No" (1.7\%). The relative strength $(94.1 \%)$ indicated that the sample of the study was very high.

When placing the responses to each difficulty faced in descending order according to the mean, the following is shown: First were "insufficient financial resources to meet the needs of poor families" and "Inadequate services provided for poor families' needs and priorities" which both recorded an average of (2.85). Second were "Difficulty of administrative procedures when accessing services for poor families" and "Weakness of the value of financial assistance provided to poor families" recording an average of (2.83). Third was "Lack of a scientific database to determine the actual needs of poor households" with an average of (2.82), fourth was "Lack of continuity of disbursement of miscellaneous aid provided to poor families", averaging (2.815), and the fifth rank was, "Lack of availability of professional staff working for the society from service providers to poor families", with an average of (2.812). The sixth rank was "Lack of cooperation of various institutions with the association in providing programs and services for poor families", with an average of (2.80). Lastly, the seventh ranked was "Lack of suitable places to provide services to poor families", with an average of (2.79). 


\begin{tabular}{||lr||}
\hline The Egyptian Journal of Social Work (EJSW) & www.ejsw.org \\
ISSN: $2356-9204$ & Vol 1, No.5, January 2018 \\
\hline
\end{tabular}

Table (9) shows the correlation matrix between the study variables

\begin{tabular}{|c|c|c|c|c|c|}
\hline Dimensions & $\begin{array}{c}\text { social } \\
\text { services }\end{array}$ & $\begin{array}{c}\text { Education } \\
\text { al services }\end{array}$ & $\begin{array}{c}\text { Health } \\
\text { Services }\end{array}$ & $\begin{array}{c}\text { Economic } \\
\text { services }\end{array}$ & $\begin{array}{c}\text { Skills } \\
\text { Development }\end{array}$ \\
\hline Social services & & & & & \\
\hline Educational services & 0.934 & & & & \\
\hline Health Services & $0.730-$ & $-0.596-$ & & & \\
\hline Economic services & 0.927 & 0.875 & $0.816-$ & & \\
\hline Skills Development & 0.850 & 0.889 & $0.398-$ & 0.701 & \\
\hline
\end{tabular}

The above table shows that there is a strong positive correlation between social and educational services where the correlation coefficient is $(0.934)$, The relationship between social services and health services was strong in the negative where the correlation coefficient was $(-0.730)$, yet the relationship between social and economic services was strong in the positive with the correlation coefficient (0.927), The correlations between social services and skills development activities were also indicative of the strength of the positive relationship, with correlation coefficient $(0.850)$. For the relationship between educational and medical services, the relationship was medium inverse, with a correlation coefficient of (-0.596). The relationship between educational and economic services reached a strong positive relationship $(0.875)$. The relationship between educational services and economic services was strong, (0.875). The relationship between educational services and skills development was also strong and positive (0.889).

While the relationship between medical services and economic relationship was strong reverse $(-0.816)$, the relationship between medical services and skills development activities was weak, with a ratio of -0.398 . Finally, the relationship between economic services and skills development activities, which reached (0.701) indicating a strong positive relationship.

Table (10) shows the results of the arrangement of services provided by

NGOs to poor households in light of the arithmetic mean and the relative strength.

\begin{tabular}{|l|l|l|l|}
\hline Arrangement & $(\mathbf{R S})$ & $($ SMA) & Programs \\
\hline 1 & $62.3 \%$ & 16.84 & Social services \\
\hline 5 & $57.6 \%$ & 12.1 & Educational services \\
\hline 2 & $61.3 \%$ & 20.25 & Health Services \\
\hline 4 & $58.9 \%$ & 15.9 & Economic services \\
\hline 3 & $59.6 \%$ & 19.6 & Skills Development \\
\hline
\end{tabular}

The results of the previous table indicate that most services provided to poor families were social programs, which placed first, followed by health programs, placing second, then skills development programs placed third, economic programs fourth, and educational programs, fifth. 


\section{The Egyptian Journal of Social Work (EJSW) www.ejsw.org \\ ISSN: 2356-9204 Vol 1, No.5, January 2018}

\section{CONCLUSIONS:}

Social protection programs are urgently needed in developing societies which suffer high rates of poverty due to the effects of economic changes (Abd El-Maseh, 2009, p. 215). This has prompted non-governmental organizations to intervene with programs that provide social protection for poor families (Amira, M, 2009, p. 28), particularly because developing countries suffer from many problems that the state cannot cope with alone (Khairullina , N.G, et al, 2016, 110-116).

The results of this study reflect the study by (Briggs, W, 2010, pp:3-24) \& (Rogers, M.L. \& Pridemare, W.A., 2013, pp:584-595), which pointed to the need to pay more attention to the social aspects of social protection programs for poor families.

There has been an increasing interest in the provision of health care as part of social protection programs, and a trend towards creating global funding for health protection, which is concerned with the establishment of a health safety net in order to channel funding to low-income countries (Basu, S., Stukler, D. \& McKee, M. Nasu Sanjay, 2014, p.145). One of the worst problems facing countries in providing social protection is poverty combined with ill health. This requires rapid intervention, in order for affected people to maintain their health, through the provision of health and treatment services (Emami, E, 2010, p.256).

It is therefore necessary to pay attention to the design of professional intervention programs with families suffering from health problems in order to reduce stress and reduce the negative effects of health vulnerability (Kim, Y, et al, 2010, pp.573).

The development of the skills of poor families is the cornerstone for success of social protection programs in all fields. The development of human ability is the most effective treatment and yet the biggest challenge in social protection programs, making skills development activities one of the areas of concern for NGOs. Social protection programs cannot be limited to physical, mental and moral support alone, but must also provide activities to build independence and improve the skills of the poor.

In their programs, NGOs need to focus on developing the skills of poor families as a basic requirement for sustainable development, enabling them to face the effects of the various pressures that poverty puts on them (Kim, Y, et al, 2010, pp.577). 


\section{The Egyptian Journal of Social Work (EJSW) www.ejsw.org \\ ISSN: 2356-9204 Vol 1, No.5, January 2018}

The study by (Jihan, A., 2011, p. 289) highlighted that poor households have a weak capacity to take care of themselves. It also showed they lack awareness of their sub-standard living conditions, or of their rights and responsibilities. And, finally, that poor households lack the ability to deal with many of the personal obstacles they face.

Finally, the results of the United Nations study (Unrisd, 2006, p. 17), confirm that addressing poverty in developing countries requires adopting a strategy that will provide job opportunities, education and skills enhancement which will integrate the poor into economic and social activity, through activating the role of civil society organizations.

The conclusion emphasizes the importance and necessity of the role played by non-governmental organizations in achieving social protection for the poor. However, the findings of the study confirm the need to improve these services to reach more people, and create higher quality services and activities that meet the needs of poor families. NGOs should undertake self-development programs for the poor as the best solution to reduce the number of poor families and the repercussions of poverty in society.

\section{Recommendation:}

The study recommends intensifying the efforts of NGO programs to give greater attention to issues of social protection by expanding their scope and extending their application to those who are not currently protected. These programs should also address the problems of lacking skills and competencies in the field of social protection in general. Programs should also aim to strengthen and support the role of centers and associations that provide social protection in order to be a country-wide tool effective in the advancement of communities.

Non-governmental organizations are one of the tools on which society depends for bridging the gaps existing in the state's goal of achieving social protection. Accordingly, the role of these organizations must be activated, their financial resources increased, and their administrative and organizational capacities developed.

Work should be undertaken to increase the diversity of social protection systems, to include the development of rural and urban women's culture in order to guarantee their rights and protect children as leaders of the future. Programs should be strengthened to improve development of individual skills, scientific and technical, therefore 
The Egyptian Journal of Social Work (EJSW) www.ejsw.org

ISSN: 2356-9204

Vol 1, No.5, January 2018

generating employment opportunities for youth and protecting them against unemployment.

\section{Determinants:}

The researcher encountered some difficulties in the application of the study, for example, some NGOs refused to participate. There was also a reluctance from some poor families to participate despite many attempts made by the researcher to convince them to take part. This was surprising especially as many of the families might have gained from the recommendations of the study, and seen organizations restructure their programs for their benefit. Another difficulty was the period of time spent on data collection.

\section{Acknowledgments:}

The researcher expresses her thanks and appreciation to all those who contributed to the achievement of this work, especially the management of the Higher Institute of Social Service in Alexandria, which contributed through the address of the administrative authorities to facilitate the researcher's task in conducting the research, as well as social workers working in NGOs and managers of organizations on their cooperation with the researcher. 


\begin{tabular}{||lr|}
\hline The Egyptian Journal of Social Work (EJSW) & www.ejsw.org \\
ISSN: 2356-9204 & Vol 1, No.5, January 2018 \\
\hline
\end{tabular}

\section{Reference}

Abd El Maseh, M. (2009). The role of NGOs in reducing poverty, master thesis, department of sociology, college of Arts, Ain-Shams University.

Abd- El Samad, M (2005). Arab Ngo's: role and challenges, civil society observer, vol (2), issue (1), Jan-Feb.

Abdul Ghaffar, S. (2005). The developmental and educational role of NGOs and cooperatives in Egypt, Cairo, Egyptian General Book Organization.

Al Rubaie, F. (2008). The role of social protection networks in protecting the poor from the risks of privatization, al-hawar Magazine, No. (2288) Retrieved from http://www.ahewar.org/debat/show.art.asp?aid=135246

Alaolma, N. (2011). Ground initiative social protection in the context of national initiatives and strategies, general organization for social security, Jordan.

Al-Namla, A. (2014). The concept of social protection and its relationship to development, working paper presented to the conference of social protection and development, Naif Arab University for Security Sciences, Saudi Arabia, 18/11/2014.

Amira, M.M. (2009). Mechanisms of NGOs in empowering poor families, unpublished master thesis, faculty of social work, Helwan University.

Basu, S., Stukler, D. \& McKee, M. (2014). An alternative mechanism for international health aid: evaluation a global social protection fund, Journal of health policy and planning, vol. (29), No.( 1),PP:127:136.

Bhargava, A., Jamison, D. T., Lau, L. J. \& Murry, C. J (2001). Modelling the effect of health on economic growth, journal of Health economics, vol.(20),No.(3), and pp:423-440.

Briggs, W.T. (2010) . A case study of family centers: approaches to serving the needs of people, Phd thesis, Department of counseling, Adult and higher education, north on Illinois University,pp:3-24.

Elkrdy, K. (2014). Social protection and development in light of the current changes a working paper, presented to the conference on social protection and development, Naif Arab University for Security Sciences, Saudi Arabia, from (24-26 / 11/2014).

Emami, E. (2008). A randomized follow up study of the general health and quality of life of an elderly, $\mathrm{PhD}$, thesis in Biomedical Sciences, Faculty of Medicine Biomedical Science Program, Montreal University.

FAO. (2012): The state of food insecurity in the world. " social protection for the poor and the weak", transition Project from protection to production, retrieved from http://www.Fao.org/economic/ptop/en 


\section{The Egyptian Journal of Social Work (EJSW) www.ejsw.org \\ ISSN: 2356-9204 Vol 1, No.5, January 2018}

Hagazy, A. (2014). The poor in the world among support and Human development policies, Cairo.

Hamoud, H. (2005). Globalization and social protection in the Arab region, working paper presented to the Lebanese American university, December 2005.

Hans, H. (2002). NGO's working and Problem of representation, Sweden Linoping University Press, http://citeseerx.ist.psu.edu/viewdoc/ download? doi=10.1.1.195.

Jihan, A. M. (2011). Professional intervention of community organizing method using social and economic development model for selfcapacity building for poor families, unpublished master thesis, Faculty of Social Work, Helwan University.

Khairullina, N. G., Ustinova, O. V., Sadykova, H. N., Oksana Vladimirovna Tretyakova, O. V. \& Bogdanova, J. Z (2016). Social protection of the poverty: problems and solutions, international journal of economics and financial issues, vol. (6), No. (s2), pp:110-116

Kim, Y., Kashy, D. A., Spillers, R. L. \& Evans, T. V. (2010).Needs Assessment of family caregivers of cancer survivors: three charts comparison, journal of psych oncology, vol (19),No.(6),PP: 573-582. doi: $10.1002 /$ pon. 1597

Lila, A. (2002). Role of NGOs in combating poverty, Cairo, Arab Network for NGOs.

Nasr, S. (2010). Issues of Social Protection in the Arab region: a fourcountry overview paper presented at the interregional workshop on social protection in an insecure era. Beirut, Lebanon, February, 27 March.

Quaider, I. (2005). Social protection: conceptualization, comprehensive vision, great socialist people's Libyan Arab Jamahiriya, secretariat of the general people's committee for culture.

Rogers, M.L. \& Pridemare, W.A. (2013). The effect of Poverty and Social protection on national homicide rates, social science research, vol. (47), No. (3), 2013,pp:584-595.

Unger, A. (2013). "Children's health in slum settings", Archives of disease in childhood, BMJ journals, vol. (98), no. (10), http://dx.doi.org/10.1136/archdischild-2011-301621.

United Nation-HABITATT. (2015). Housing and slum upgrading. Retrieved on May 24, 2016 at: http://unhabitat.org/ urban- themes/ housing-slum-upgrading/.

United Nations. (2008). United Nation Development Program Human Development Report, Egypt, Retrieved from http://hdr.undp.org/en/ countries/profiles/EGY 
The Egyptian Journal of Social Work (EJSW) www.ejsw.org

Unrisd. (2006). Transformative social policy, lessons from UNRISD research, United Nations Research Institute for social development, UNRISD Research and policy brief 5, Retrieved from http://www.Unrisd.org/Publications/rpb5e.

Wagle, U. R. (2016). How much do social protections matter to poverty and inequality? An insight from Asian experiences, Global social policy, vol. (17), No. (2), pp:137-167

Waqas, M. \& Awan, M. S. (2017). Social Protection, Gender, and Poverty: Application of Social Protection Index, Journal of Policy Practice, vol (16), No. (4). 